\title{
APAKAH TINGKAT KEBAHAGIAAN BISA MENJELASKAN HASIL BELAJAR SISWA SEKOLAH DASAR?
}

\author{
Lalu Hamdian Affandi ${ }^{1, *)}$, Heri Hadi Saputra ${ }^{2}$, \& Husniati ${ }^{3)}$ \\ 1), 2), 3), 4) Universitas Mataram, Mataram, Indonesia \\ E-mail: hamdian.fkip@unram.ac.id
}

\begin{tabular}{ll}
\hline ARTICLE INFO & ABSTRACT \\
\hline Article history & Tujuan dari penelitian ini adalah untuk menguji kebahagiaan sebagai \\
Received: August 2, 2020 & variable penjelas hasil belajar. Responden dalam penelitian ini adalah 222 \\
Revised: August 3, 2020 & orang siswa kelas 4-6 sekolah dasar di Kota Mataram. Data diperoleh \\
Accepted: August 12,2020 & dengan angket dan dokumentasi. Angket dalam penelitian ini dikembangkan \\
& dari Multidimensional Student's Life Satisfaction Scale (MSLSS) Huebner. \\
Keywords: & Sedangkan dokumentasi digunakan untuk mengumpulkan data tentang hasil \\
kebahagiaan siswa, hasil & belajar siswa. Data dalam penelitian ini dianalisis dengan teknik Korelasi \\
belajar, siswa sekolah dasar & Pearson Product Moment. Penelitian ini menyimpulkan bahwa kebahagiaan \\
& siswa tidak bisa dijadikan sebagai variable penjelas hasil belajar. Temuan \\
& penelitian ini berbeda dengan kesimpulan penelitian sebelumnya yang \\
& menjadikan tingkat kebahagiaan sebagai predictor hasil belajar siswa. \\
& Selanjutnya, penelitian ini menyarankan agar dilakukan penelitian yang \\
& lebih sistematis dan ketat dengan melibatkan siswa dengan karakteristik \\
& yang lebih beragam.
\end{tabular}

\section{A. PENDAHULUAN}

Implementasi Kurikulum 2013 (K13) membawa perubahan besar terhadap proses pembelajaran di kelas. Fitur utama K13 terletak pada 3 hal, yaitu pembelajaran tematik, pendekatan saintifik, dan aplikasi penilaian autentik sebagai pendekatan asesmen yang diakukan guru. Pembelajaran saintifik merupakan prosedur pembelajaran yang terpusat pada tema atau topik tertentu sebagai pengikat materi dari berbagai mata pelajaran. Pendekatan saintifik merupakan pendekatan pembelajaran yang menjadikan siswa sebagai subyek belajar aktif yang melakukan tahapan mengamati, menanya, mengumpulkan informasi, menalar, dan mengkomunikasikan hasil belajarnya. Pendekatan saintifik memosisikan guru sebagai fasilitator yang bertugas menjamin aktivitas belajar siswa berlangsung sesuai tahapan yang seharusnya. Pembelajaran dengan pendekatan saintifik dalam K13 dibarengi dengan sistem penilaian autentik, yaitu sistem penilaian yang terarah kepada keseluruhan hasil belajar siswa dalam segala aspeknya. Penilaian yang dilaksanakan guru dalam pembelajaran disasarkan pada bukan hanya aspek kognitif yang diperoleh dari jawaban siswa terhadap soal yang diberikan 
guru, melainkan pula mencakup aspek afektif dan keterampilan yang diperoleh guru dari sumber informasi lain (Maulyda et al., 2020).

K13 menghendaki munculnya guru yang kreatif dan siswa aktif. Kreativitas guru dibutuhkan dalam merancang pembelajaran tematik bagi siswa dengan memastikan bahwa semua siswa terlibat maksimal dalam tahapan pembelajaran yang diamanatkan dalam pendekatan saintifik. Keterlibatan aktif siswa dalam pembelajaran menjadikan siswa sebagai pusat belajar yang harus dilayani untuk mengembangkan segenap potensi yang dimilikinya. Sebagai subyek belajar, siswa menunjukkan keterlibatan belajarnya dengan menjalani tahapan pembelajaran seperti memperhatikan informasi yang disajikan guru, merumuskan pertanyaan atau terlibat dalam diskusi, melakukan pengamatan untuk mengumpulkan informasi, berdiskusi dengan temannya untuk menafsirkan informasi yang diperolehnya, serta mengkomunikasikan temuannya kepada guru dan teman-temannya. Rangkaian aktivitas siswa yang difasilitasi oleh guru tersebut diharapkan bisa membangun kebiasaan belajar pada diri siswa (Hidayati et al., 2020). Dengan cara ini, diharapkan siswa dapat menemukan kesenangan dalam aktivitas pembelajaran yang dijalaninya.

Implementasi K13 tidaklah tanpa tantangan yang perlu diperhatikan demi keberhasilan pencapaian tujuan pendidikan. Tantangan implementasi K13 dilaporkan berasal dari berbagai lapisan stakeholder pendidikan, mulai dari pemerintah, guru, serta siswa dan orang tuanya. Tantangan yang dirasakan oleh guru antara lain berkaitan dengan aplikasi pembelajaran tematik di kelas, penggunaan media pembelajaran yang sesuai dengan tema yang hendak dibelajarkan, serta penggunaan teknologi informasi dalam pembelajaran (Krissandi dan Rusmawan, 2015; Mukminah, 2018). Pemahaman guru terhadap karakteristik K13 dilaporkan masih perlu ditingkatkan, terutama yang berkaitan dengan aspek penilaian. Ketidaksiapan guru tersebut disinyalir muncul sebagai akibat dari kurangnya sosialisasi yang dilakukan terhadap guru (Mustika dan Gunansyah, 2018).

Ketidaksiapan implementasi K13 selanjutnya berimbas pada siswa sebagai subyek belajar. Dalam implementasi pembelajaran tematik, siswa dilaporkan mengalami kebingungan karena banyaknya materi yang harus mereka pelajari dalam durasi waktu yang sangat terbatas (Krissandi dan Rusmawan, 2015). Oleh sebab itu, menjadi wajar jika siswa merasa terbebani dengan implementasi K13, terutama ketika menjelang ujian akhir semester (Wardana dan Dinata, 2016). Dalam kaitan dengan proses pembelajaran, banyak guru yang dilaporkan mengalami kegamangan dalam merencanakan dan melaksanakan pembelajaran tematik sehingga menyebabkan mereka melaksanakan pembelajaran yang terpusat pada guru -ketika 
kurikulum menghendaki pembelajaran yang berpusat pada siswa (Krissandi dan Rusmawan, 2015). Akibatnya keterlibatan siswa dalam pembelajaran menjadi sangat sedikit (Endayanti dan Rahmawati, 2019). Tekanan terhadap siswa menjadi semakin besar karena selain kebingungan dan beban belajar yang dirasa terlalu banyak, tuntutan dan ekspektasi dari sekolah juga dirasa terlalu tinggi (Gusniarti, 2002).

Analisis yang lebih dalam berdasarkan kesesuaian antara tuntutan kompetensi yang harus dikuasai siswa dalam K13 dengan intake yang dimiliki siswa pada kelas awal sekolah dasar menunjukkan bahwa tuntutan K13 tersebut terlalu tinggi. Hal ini tentunya membuat kerja guru untuk memfasiitasi siswa mencapai tujuan pembelajaran menjadi semakin keras. Kerasnya usaha guru tersebut pastinya akan berdampak pada beban yang harus dipikul siswa. Beban yang terlalu besar tentunya akan mempengaruhi tingkat kebahagiaan siswa, sikap positif siswa terhadap aktifitas belajar, serta kepuasan siswa terhadap kinerja guru dan sekolah.

Kebahagiaan dan sikap positif siswa diperlukan untuk membangun image bahwa sekolah bukanlah tempat yang membosankan -jika tidak ingin dikatakan menyeramkan. Jauh sebelum K13 diterapkan, kurikulum Indonesia sudah disinyalir sebagai kurikulum yang overloaded karena padatnya materi yang harus dipelajari siswa. Situasi tersebut tentunya berimbas pada sikap siswa terhadap aktifitas belajar, guru, sekolah, serta system pendidikan pada umumnya. Artinya, jika siswa tidak betah dan merasa tertekan dalam proses pembelajaran karena tuntutan kurikulum yang terlalu tinggi, maka kita sulit berharap kepada siswa untuk menjadi pebelajar seumur hidup. Perasaan tertekan dalam proses belajar tentunya akan menjadi penghambat bagi siswa untuk mengulangi dan membiasakan aktifitas belajar. Pada saat yang sama, aktifitas belajar akan selalu dibutuhkan siswa karena nantinya mereka akan selalu dihadapkan pada situasi baru yang menuntut penyesuaian diri dan pemecahan masalah. Dan penyesuaian diri dan pemecahan masalah tersebut hanya bisa diperoleh melalui aktifitas belajar.

Kebahagiaan juga berperan penting dalam perkembangan siswa, khususnya yang berkaitan dengan perkembangan psikologis siswa. Pengalaman membahagiakan ditemukan mempengaruhi self esteem anak (Grimaldy, Nirbayaningtyas, dan Haryanto, 2017). Dengan kata lain, semakin sering seorang anak mendapatkan pengalaman membahagiakan, semakin baik dia menilai dirinya sendiri. Dalam konteks pendidikan, proses belajar mestinya menjanjikan pengalaman membahagiakan bagi siswa. Hanya dengan cara itu sekolah dan system pendidikan akan berhasil membangun self esteem yang baik bagi siswa sehingga mereka berkembang menjadi individu yang sehat secara psikologis. 
Kebahagiaan adalah konstruk unik yang terdiri dari aspek-aspek kontekstual yang kuat (Anggoro dan Widhiarso, 2010). Besarnya pengaruh konteks terhadap kebahagiaan membuat keadaan yang melingkupi individu tidak bisa dinegasikan. Karena konteks yang melingkupi individu berbeda, maka tingkat kebahagiaan individu pun menjadi relative. Satu aspek mungkin membuat seorang individu bahagia, namun aspek yang sama belum tentu membuat individu lain merasakan hal yang sama. Selain relative, kebahagiaan juga bersifat subyektif. Subyektifitas kebahagiaan merupakan property individual yang melekat pada rasa yang dimiliki oleh manusia terhadap sebuah obyek. Satu obyek mungkin bisa menjadi sumber kebahagiaan bagi seseorang namun tidak bagi orang lain.

Berdasarkan premis di atas, dapat disimpulkan bahwa tingkat kebahagiaan siswa dapat didefinisikan sebagai penilaian subyektif siswa terhadap kehidupannya. Dalam pengukurannya, tingkat kebahagiaan diklasifikasi berdasarkan aspek afektif dan kognitif. Aspek afektif adalah dimensi emosional individu terhadap faktor eksternal yang mendatangkan kebahagiaan. Pada aspek ini, kebahagiaan siswa diidentifikasi melalui intensitas dan frekwensi perasaan positif yang dimiliki siswa. Pada sisi lain, aspek kognitif dari kebahagiaan seringkali diekuivalenkan dengan kepuasan hidup, yaitu penilaian siswa terhadap kualitas kehidupannya secara keseluruhan (Bender, 1997).

Factor yang mendatangkan kebahagiaan berbeda dari satu masyarakat ke masyarakat lain sebagaimana perbedaan persepsi terhadap sumber kebahagiaan berdasarkan umur dan level perkembangan individu. Bagi masyarakat Indonesia, kebahagiaan terdiri dari aspek ikatan kekeluargaan, relasi sosial, kebutuhan spiritual, dan prestasi personal (Anggoro dan Widhiarso, 2010). Bagi guru, kebahagiaan terdiri dari karakter positif dan perasaan positif. Karakter positif yang harus dimiliki guru antara lain bermasyarakat, menjadikan agama sebagai motivasi, terbuka dalam bekerja sama, semangat dalam bekerja, serta bersyukur menjadi guru. Perasaan positif pada diri guru muncul ketika siswa mengikuti pelajaran dan melanjutkan pendidikan ke jenjang yang lebih tinggi, masyarakat mendukung pendidikan, adanya kesatuan kerja, adanya dukungan sosial, serta dapat menunjukkan identitas diri sebagai guru (Irianto dan Subandi, 2015). Bagi siswa sekolah dasar, hubungan teman sebaya, hubungan guru-siswa, dan pembelajaran akademik adalah 3 prediktor signifikan perasaan positif (Wijayanti dan Sulistiobudi, 2018).

Dalam penelitian ini, kebahagiaan siswa diukur dengan kuesioner yang dikembangkan dari Multidimensional Student's Life Satisfaction Scale (MSLSS). Instrumen tersebut dikembangkan oleh Huebner untuk mengukur kepuasan hidup siswa pada domain keluarga, 
teman sebaya, sekolah, dan lingkungan di mana siswa hidup (Bender, 1997; Huebner, Seligson, Valois, and Suldo, 2006). Luasnya cakupan MSLSS membuat peneliti berinisiatif untuk menspesifikkan domain pengukuran hanya pada kehidupan sekolah saja, terutama pada proses pembelajaran yang dialami siswa di kelas.

Selain mempengaruhi self esteem (Grimaldy, Nirbayaningtyas, dan Haryanto, 2017), kebahagiaan juga ditemukan mempengaruhi keterlibatan belajar dan hasil belajar siswa (Lewis, Huebner, Malone, and Valois, 2011). Pada level pendidikan tinggi, kepuasan hidup sebagai salah satu komponen kebahagiaan merupakan predictor hasil belajar siswa (grade point average -GPA), bahkan ketika factor lainnya seperti sikap dan jenis kelamin dikontrol (Rode, Arthaud-Day, Mooney, Near, Baldwin, Bommer, and Rubin, 2005). Oleh sebab itu, tidak mengherankan jika tingkat kebahagiaan perlu dianalisis untuk memahami hasil belajar siswa.

Hubungan antara kebahagiaan dan hasil belajar bisa dijelaskan dengan keterkaitan antara aspek afektif dan aspek kognitif dalam kerja otak. Ketika perasaan ( $m o o d)$ positif muncul dalam struktur otak, hal tersebut akan mempengaruhi proses pengolahan informasi yang berlangsung di dalam working memory, yaitu ketika otak melakukan pengkodean informasi. Berdasarkan riset neuroscience, perasaan positif tertentu akan menstimulasi munculnya informasi yang relevan dalam memori jangka panjang, merangsang kreatifitas, serta pengalokasian sumber daya kognitif dalam proses atensi terhadap obyek yang dipersepsi memiliki kemiripan dengan sumber kebahagiaan (Pintrich, 2003; Moreno, 2010; Sternberg and Sternberg, 2012). Proses pengolahan dan pemanggilan informasi merupakan salah satu proses penting yang dilalui siswa dalam proses pembelajaran. Pada level pembelajaran yang tinggi seperti problem solving, kreatifitas menjadi salah satu keterampilan penting yang harus dilatih dan dikembangkan. Perasaan positif tertentu akan mendorong siswa untuk menjadi lebih kreatif.

Sebaliknya, ketika perasaan negative muncul, maka kerja otak pun menjadi terganggu. Perasaan negative dalam bentuk peningkatn kadar stress kerap dialami siswa menjelang pelaksanaan ujian akhir semester (Wardana dan Dinata, 2016). Stres siswa juga berkorelasi dengan tuntutan dan harapan sekolah, terutama tuntutan akan prestasi dan upaya untuk mencapainya (Gusniarti, 2002). Ketika siswa mengalami stress, biasanya perhatian siswa akan terarah pada sumber stress dan upaya untuk menghilangkan atau mengurangi stress. Pengurangan sumber daya kognitif tersebut tentunya berimplikasi pada pemrosesan informasi yang harus dilakukan oleh siswa di dalam pembelajaran. Individu yang belajar dalam suasana stress dilaporkan mengingat materi pelajaran lebih sedikit dibandingkan dengan individu yang belajar dalam suasana yang tidak tertekan (Schwabe and Wolf, 2010). Semakin banyak sumber 
daya kognitif yang tersita oleh stress, semakin kecil perhatian siswa yang dialokasikan pada pembelajaran, semakin sedikit peluang siswa untuk mencapai hasil belajar yang diharapkan.

Penelitian ini bertujuan untuk mengeksplorasi kebahagiaan subyektif (subjective wellbeing) yang dirasakan siswa ketika mereka menjalani aktifitas belajar di sekolah. Secara lebih spesifik, penelitian ini bertujuan untuk mendeskripsikan keterkaitan antara kebahagiaan subyektif dengan hasil belajar siswa di sekolah.

\section{B. METODE PENELITIAN}

Penelitian ini bertujuan untuk menguji hubungan antara tingkat kebahagiaan dengan hasil belajar siswa sekolah dasar. Responden dalam penelitian ini adalah 222 siswa kelas 4-6 sekolah dasar di Kota Mataram. Data tentang tingkat kebahagiaan siswa dikumpulkan dengan angket yang dikembangkan berdasarkan MSLSS dengan spesifikasi pada aspek-aspek pembelajaran yang dialami siswa. Sedangkan data tentang hasil belajar siswa dikumpulkan dengan melakukan dokumentasi terhadap nilai rapot siswa yang dibuat oleh guru. Data kemudian dianalisis dengan teknik Korelasi Product Moment untuk mengetahui kuat dan arah hubungan.

\section{HASIL DAN PEMBAHASAN}

Deskripsi responden dalam penelitian ini tergambar pada table di bawah ini.

Tabel 1. Deskripsi Responden Penelitian

\begin{tabular}{cccc}
\hline Kelas & Frekuensi & Prosentase & Nilai \\
\hline 4 & 68 & 30.63063 & 81.8 \\
5 & 67 & 30.18018 & 89.7 \\
6 & 87 & 39.18919 & 84.2 \\
\hline $\mathrm{N}$ & 222 & & \\
\hline
\end{tabular}

Hasil analisis data menunjukkan koefisien $\mathrm{r}$ sebesar 0.110, dengan nilai p 0.101 lebih besar dari 0.05. Dengan demikian dapat disimpulkan bahwa korelasi antara kebahagiaan siswa dengan hasil belajar tidak signifikan. Artinya, perubahan pada kebahagiaan siswa tidak diikuti oleh perubahan pada hasil belajar siswa.

Analisis data mengarahkan peneliti pada kesimpulan bahwa korelasi antara kebahagiaan siswa dengan hasil belajar tidak signifikan. Dengan kata lain, kebahagiaan siswa tidak dapat dijadikan sebagai penjelasan yang sahih terdapat hasil belajar. Fakta ini berbeda dengan kesimpulan dari beberapa penelitian lain yang menyimpulkan bahwa tingkat kebahagiaan siswa adalah predictor keterlibatan dan hasil belajar siswa (Lewis, Huebner, 
Malone, and Valois, 2011; Rode, Arthaud-Day, Mooney, Near, Baldwin, Bommer, and Rubin, 2005).

Sebagaimana yang kita pahami bersama, bahwa hasil belajar merupakan konstruk yang sering dianalisis berdasarkan komponen afektif, kognitif, dan keterampilan. Hasil belajar afektif merupakan perubahan pada aspek sikap yang dimiliki oleh siswa terhadap obyek tertentu seperti materi yang diajarkan, proses belajar, guru, dan sebagainya. Aspek kognitif berkenaan dengan perubahan pada struktur mental atau kapasitas berfikir yang dimiliki oleh siswa. Sedangkan aspek keterampilan merupakan perubahan pada kemampuan siswa dalam melakukan prosedur-prosedur tertentu dengan melibatkan manipulasi motoriknya. Dalam penelitian ini, hasil belajar yang diperoleh dari guru adalah hasil belajar kognitif yang diambil dari penilaian terhadap kemampuan siswa menjawab dengan benar soal atau masalah yang disajikan oleh guru.

Selain itu, hasil belajar siswa juga ditentukan oleh banyak factor yang berasal dari luar diri siswa, misalnya ketersediaan sarana dan sumber belajar serta dukungan orang tua. Keberadaan sarana dan sumber belajar yang memadai tentunya menjadi penunjang keberhasilan belajar siswa. Ketika siswa membutuhkan informasi tambahan tentang materi pelajaran tertentu dan ia tidak mendapatkannya dari guru, ia bisa mendapatkan informasi yang dibutuhkan tersebut dari sumber lain, dengan catatan sarana dan sumber belajar tersedia dengan mencukupi. Pada saat yang sama, keterlibatan orang tua dalam proses belajar anak berpengaruh besar terhadap capaian belajar siswa sekolah (Wilder, 2014). Sebagai contoh kecil, ketika seorang anak mengalami kesulitan menyelesaikan tugas yang diberikan guru, kehadiran orang tua untuk memotivasi dan membantu menyelesaikan tugas menjadi factor kunci dengan pengaruh yang sangat besar.

Terakhir, karakteristik siswa juga patut diduga sebagai variable moderator yang menentukan hubungan antara tingkat kebahagiaan dengan hasil belajar. Bagi siswa tertentu, kebahagiaan dalam proses belajar mungkin tidak cukup signfikan dalam mempengaruhi keterlibatan belajarnya. Siswa dengan motivasi instrinsik atau dukungan yang tinggi dari orang tua dalam proses belajar tentunya memiliki usaha yang lebih besar untuk mencapai hasil yang maksimal. Dalam penelitian ini, responden termasuk siswa-siswa dengan nilai yang sangat baik menurut guru (rerata nilai siswa di atas 80). Artinya, responden dalam penelitian ini adalah siswa terbaik yang patut diduga memiliki motivasi instrinsik yang cukup tinggi. 
Affandi, dkk. (2020). Apakah Tingkat Kebahagiaan...

\section{SIMPULAN}

Penelitian ini menyimpulkan bahwa kebahagiaan siswa tidak bisa dijadikan sebagai variable untuk menjelaskan hasil belajar siswa. Temuan penelitian ini berbeda dengan kesimpulan penelitian sebelumnya yang menjadikan tingkat kebahagiaan sebagai predictor hasil belajar siswa. Selanjutnya, penelitian ini menyarankan agar dilakukan penelitian yang lebih sistematis dan ketat dengan melibatkan siswa dengan karakteristik yang lebih beragam.

\section{DAFTAR PUSTAKA}

Anggoro, W.J., Widhiarso, W. 2010. Konstruksi dan Identifikasi Properti Psikometris Instrumen Pengukuran Kebahagiaan Berbasis Pendekatan Indigenous Psychology: Studi Multitrait-Multimethod. Jurnal Psikologi, 37(2); 176-188

Bender, T.A. 1997. Assessment of Subjective Well-Being during Childhood and Adolescence. In Gary D. Phye (ed.). Handbook of Classroom Assessment: Learning, Achievement, and Adjustment. p199-225. San Diego, CA; Academic Press

Endayanti, T., dan Rahmawati, I. 2019. Analisis Pembelajaran Matematika dalam Kurikulum 2013 Revisi pada Kelas IV Sekolah Dasar. Jurnal Penelitian Guru Sekolah Dasar, $7(1) ; 2601-2612$

Grimaldy, D.V., Nirbayaningtyas, R.B., dan Haryanto, H.C. Efektifitas Jurnal Kebahagiaan dalam Meningkatkan Self Esteem pada Anak Jalanan. Inquiry, Jurnal Ilmiah Psikologi, 8(2); 100-110

Gusniarti, U. 2002. Hubungan antara Persepsi Siswa terhadap Tuntutan dan Harapan Sekolah dengan Derajat Stres Siswa Sekolah Plus. Psikologika, VII(13); 53-68

Hidayati, V. R., Wulandari, N. P., Maulyda, M. A., Erfan, M., \& Rosyidah, A. N. K. (2020). Literasi Matematika Calon Guru Sekolah Dasar dalam Menyelesaikan Masalah PISA Konten Shape \& Space. JPMI: Jurnal Pembelajaran Matematika Inovatif, $3(3), 1-10$.

Huebner, E.S., Seligson, J.L., Valois, R.F., and Suldo, S.M. 2006. A Review of The Brief Multidimensional Student's Life Satisfaction Scale. Social Indicator Research. DOI $10.1007 / \mathrm{s} 11205-005-5395-9$

Irianto, dan Subandi. 2015. Studi Fenomenologis Kebahagiaan Guru di Papua. Gadjah Mada Journal of Psychology, 1(3); 140-166

Krissandi, A.D.S., dan Rusmawan. 2015. Kendala Guru Sekolah Dasar dalam Implementasi Kurikulum 2013. Cakrawala Pendidikan, tahun XXXIV(3); 457-467 
Affandi, dkk. (2020). Apakah Tingkat Kebahagiaan...

Lewis, A.D., Huebner, E.S., Malone, P.S., and Valois, R.F. 2011. Life Satisfaction and Student Engagement in Adolescents. Journal of Youth Adolescence, 40; 249-262

Maulyda, M. A., Umar, Erfan, M., Hidayati, V. R., \& Haryati, L. F. (2020). IMPLEMENTATION OF STAD TYPE COOPERATIVE LEARNING TO IMPROVE MATHEMATICAL LEARNING OUTCOMES CLASS VIII STUDENTS. Jurnal Ilmiah Pendidikan Matematika, 5(1), 1-12.

Moreno, R. 2010. Educational Psychology. Danvers, MA; John Wiley \& Sons Inc

Mukminah. 2018. Problematika Penerapan Kurikulum 2013 (K13) pada Madrasah Ibtidaiyah Nurul Ulum Mertak Tombok Praya Kabupaten Lombok Tengah. JUPE, 3(3); 1-4

Mustika, A.A.C., dan Gunansyah, G. 2018. Kemampuan Guru Sekolah Dasar dalam Sistem Penilaian Kurikulum 2013 Kabupaten Tuban: Studi Komparasi Sekolah Induk Kluster Pelaksana Kurikulum 2013. Jurnal Penelitian Guru Sekolah Dasar, 6(6); 894-903

Pintrich, P.R. 2003. Motivation and Classroom Learning. In William M. Reynolds and Gloria E Miller (eds.). Handbook of Psychology, Volume 7: Educational Psychology. p103122. New Jersey; John Wiley \& Sons Inc.

Rode, J.C., Arthaud-Day, M.L., Mooney, C.H., Near, J.P., Baldwin, T.T., Bommer, W.H., and Rubin, R.S. 2005. Life Satisfaction and Student Performance. Academy of Management Learning \& Education, 4(4); 421-433

Schwabe S., and Wolf, O.T. 2010. Learning under Stress Impairs Memory Formation. Neurobiology of Learning and Memory, 93; 183-188

Sternberg, R.J., and Sternberg, K. 2012. Cognitive Psychology, Sixth Edition. Belmont, CA; Wadsworth, Cengage Learning

Wardana, M.S., dan Dinata, I.M.K. 2016. Tingkat Stres Siswa Menjelang Ujian Akhir Semester di SMAN 4 Denpasar. E-Jurnal Medika, 5(9); 1-4

Wijayanti, P.A.W., dan Sulistiobudi, R.A. 2018. Peer Relation sebagai Prediktor Utama Subjective Well-Being Siswa Sekolah Dasar. Jurnal Psikologi, 17(1); 56-67

Wilder, S. 2014. Effect of Parental Involvement on Academic Achievement: a Meta-analysis. Educational Review, 66(3); 377-397 